\title{
Laser Nozzle Device
}

National Cancer Institute

\section{Source}

National Cancer Institute. Laser Nozzle Device. NCI Thesaurus. Code C50292.

A device through which a laser beam emerges. 